\title{
Determinants of Middle Managers' Leadership in the Vietnamese Economic-Defense Enterprises
}

\author{
Cuong Van HOANG ${ }^{1}$, Ngoc Huu NGUYEN ${ }^{2}$, Loan Quynh Thi NGUYEN ${ }^{3}$, Manh Dung TRAN ${ }^{4}$
}

Received: June 02, 2020 Revised: June 21, 2020 Accepted: July 09, 2020

\begin{abstract}
The purpose of this study is to investigate factors affecting the leadership capacity of middle managers and then evaluate the corresponding effect on the performance of subordinates in Vietnamese economic and defense enterprises. Data for the study was collected from questionnaire survey of 15 economic and defense enterprises, preceded by in-depth interviews with respondents who are subordinates of the departments/divisions of these enterprises. The research used logistic regression estimator to address econometric issues and to improve the accuracy of the regression coefficients. Our results show that the determinants of the leadership capacity of mid-level managers in defense and economic enterprises include: (i) personal qualities and qualities of managerial officials (understanding, courage), fairness, assertiveness and compliance), and leadership behaviors of two leadership styles - (ii) a transforming leadership style (influenced by ideals, inspirations, concerns) subordinates, stimulating intellect) and (iii) transactional leadership style (rewarding, detecting and handling problems for subordinates). Based on these results, our study suggests that middle managers should possess superior knowledge, care more about subordinates, understand the strengths and weaknesses of each subordinate, always be creative, assertive and courageous people as well as have high standards of competency and morality in order to become outstanding leaders in Vietnamese economic and defense enterprises.
\end{abstract}

Keywords: Leadership, Middle Managers, Economic-Defense Enterprises, Vietnam

JEL Classification Code: E24, J24, M12, M54, O15

\section{Introduction}

Leadership is a key element in the success (or failure) of most organizations due to the vital role of leaders in providing the necessary guidance to help the organization achieve its goals. Defense-economic businesses, as well as other leading civil-economic businesses, need to have

\footnotetext{
${ }^{1}$ First Author. Associate Professor, National Economics University, Vietnam. Email: cuonghv@neu.edu.vn

${ }^{2}$ Researcher, Ministry of Defense, Vietnam.

Email: huungocbd12@gmail.com

${ }^{3}$ Corresponding Author. Lecturer, School of Banking and Finance, National Economics University, Vietnam [Postal Address: 207 Giai Phong Road, Dong Tam Ward, Hai Ba Trung District, Hanoi, 116000, Vietnam] Email: quynhloannguyen511@gmail.com

${ }^{4}$ Associate Professor, National Economics University, Vietnam. Email: manhdung@ktpt.edu.vn

(c) Copyright: The Author(s)

This is an Open Access article distributed under the terms of the Creative Commons Attribution Non-Commercial License (http://Creativecommons.org/licenses/by-nc/4.0/) which permits unrestricted noncommercial use, distribution, and reproduction in any medium, provided the original work is properly cited.
}

talented and creative managers in order to be successful in the 21 st century. If such, they need to be equipped with high skills, intellect, a sense of responsibility, dedication and other advantageous factors that bear personal marks. One of the most important criteria for selecting effective managers is competence. The requirement for a manager is that the manager must determine the goals of the organization as their own. Today, when measuring the performance of an organization, better results are increasingly being mentioned, not as an organization's resources, but in terms of its human resources and competencies, and thus leadership has become one of the organization's top priorities.

The characteristics of leadership in the military are the high discipline and priority for the performance of tasks attached to the defense. However, for an enterprise to develop in a market mechanism, it must also comply with the corporate governance principles of commercial businesses. Therefore, the contingent of cadres at all levels of defense economic enterprises, in addition to the general management and operation capability, requires the satisfaction of the commanding and management capacity associated with the 
task of ensuring the National Defense. In order to carry out their important task, middle managers in defense economic enterprises must identify the leadership capabilities needed in their future development, while leading subordinates to perform their tasks effectively, as well as meet the requirements of the leaders.

Therefore, this study will examine factors that affect the leadership capacity of mid-level managers and their influences on the performance of subordinates' work in economic and defense enterprises. The following key questions are investigated: (1) What are the constituent elements of leadership of middle managers? (2) What are the influences on leadership components of middle managers on the performance of subordinates? (3) What should be done to develop and improve the leadership capacity of mid-level managers in defense economic enterprises? These are also the gaps that have not been studied in Vietnam's defense economic enterprises - a specific area that performs both economic and defense tasks, in the context of economic integration, and the requirement of performing new tasks from the Prime Minister and the Ministry of Defense.

\section{Theoritical Framework}

\subsection{Characteristics of Leadership and Commanders in the Army}

\section{Leadership in the military is operated under a unified leadership and leadership mechanism}

It is a strict observance of the Party's principle of absolute and direct leadership in all aspects of the military. Party organizations generally have to perform two functions well. Unit leaders perform well the tasks assigned, and seek advice from superiors on the guidelines and measures to lead unit building, military construction. The system of agencies in the unit has the task of guiding the implementation and organizing the implementation of the guidelines and measures of the party organization, the commanding orders of the commander. The commander must adhere to, and obey the principle of collective leadership assigning individuals to be in charge, having the leadership task to direct the implementation of the goals, directions, tasks and solutions determined by the party organization. In the course of implementation, proactively grasping and analyzing forecasts of the situation and development factors in practice in order to propose contents and policies for leadership measures.

\section{Leadership in the military is organized according to a strict structured system, strict discipline}

Military units, in general, and enterprises in the army, in particular, are organized and staffed according to the characteristics and tasks of each unit, but generally there is a clear leadership hierarchy at each level. Each level has its own functions and duties, but it is aimed at fulfilling the goal of completing all assigned tasks in any situation. The commanding leadership of the military units also differs with its own characteristics. That is, the commander can issue orders to direct subordinates, and can also issue orders to each soldier in the unit to carry out a certain task. Submission between leaders and commanders is determined by the nature and traditions of the People's Army. Every serviceman must be obliged to make ten vows of honor, 12 disciplinary actions, and military duties. It is this feature that has created a high degree of discipline and unity in action, a sense of compliance with the orders of superiors of military personnel and employees in military units.

Leadership in the army always shows the democracy, solidarity, and comradeship between officers and soldiers

Leadership in the army also has its own characteristics, which is in the military personnel relationship according to the traditional military characteristics, "soldiers are not full, officials are not called to be hungry, soldiers do not have cold clothes. You must not call you cold". A leader must always show justice as a brother, gentle as his sister, as gentle as a mother, even as a father. These traditional characteristics create comradeship and brotherhood in the army. It creates and unifies in purpose, motivation, and high sense of responsibility in obeying orders.

The leaders and commanders of the units in the army are experienced and trained in practice close to their responsibilities

Leaders and commanders in the army are those who are trained, developed at lower levels, selected and carefully fostered by their superiors. Each level they undergo must demonstrate the leadership ability of their subordinate units to fulfill well all tasks, acknowledged by their subordinates, peers and superiors. This feature clearly confirms the position and prestige of their leadership ability, in command leadership, which is the basis and conditions to conquer and persuade and lead subordinates to perform the tasks of the unit.

Leadership in the military is always subject to the provisions of elements of the traditional nature of the army and the nation.

Our army has a tradition of solidarity, strict self-discipline, decisiveness, determination to win, sticking flesh and blood to the people, for the people serving, with the spirit of international solidarity, the spirit of willingness to sacrifice and complete mission. These traditions greatly influence the leadership, decision-making from the commander. 
The commander must always pay attention to the performance of his orders under the command of the superior commander, perform military tasks, and must take into account the factors that ensure the rights and aspirations of legitimate interests of the public, share with the public, and perform well the tasks of international relations, and foreign defense; resolutely perform and complete tasks in all situations, fulfill well the functions of the army, production labor, and army.

\subsection{Determinants of Leadership Capacity}

\subsubsection{Group of Factors That Belong to a Leader's Characteristics/Qualities}

In recent years, capacity research has attracted increasing attention and interest. Many attempts have been made by scholars to study the capacity (Boyatzis, 1982; McCleland, 1973; McLagan, 1989; Prahalad \& Hamel, 2006). Capacity models, in addition to being seen as a focal point for planning, organizing, integrating and improving all aspects of the human resource management system (McLagan, 1980), are also considered as a way to an approach focused on improving organizational performance (Rothwell \& Lindholm, 1999). There are many studies on individual characteristics/qualities of leaders. In this study, the author has chosen the approach and classification of Peterson and Seligman (2004) as the basis for the approach of individual points/qualities of leaders; at the same time, through qualitative research, develop the characteristics/personal qualities of middle managers to suit the context of defense economy in Vietnam. The characteristics/qualities examined by the study included five qualities/characteristics:

\section{(1) Understanding}

Understanding is assessed through creative thinking, curiosity, readiness to absorb new things, consideration of perspectives different from ones' own, and never stop learning. At the same time, the leader has a deep understanding and will be able to assess, cover the situation, cover the work, but will not overlook important details. Understanding also manifests itself in the ability to predict situations, to be flexible in handling situations and in giving ideas for quick and effective work settlement. Understanding is evident in everyday work behaviors (Judge et al., 2002) as well as in the way they deal with organizational changes.

\section{(2) Courage}

According to Peterson and Seligman (2004), courage shows the willing to face difficulties, challenges and dangers, and persevere in pursuing and getting things done despite many difficulties and obstacles. Courage does not mean fearlessness; courage has to do what one is afraid to do. It is the ability to leave behind what is familiar, and enter a new land. Courage is the right work, the honesty, integrity - what builds the trust between leaders and subordinates. Courage is also expressed by the willingness to face difficulties, challenges and dangers, unreliability, giving in to difficulties, hardships, deprivation and a willingness to accept, withstand pressure and be able to overcome the pressure of work. The basic measure for assessing a person is not in the times when they live in joy and comfort, but in times when they struggle with challenges.

\section{(3) Assertiveness}

Assertiveness shows initiative in deciding all the jobs; it is the ability to make decisions on an action plan against a situation with many different opinions as well as a lack of hesitation in situations and opportunities to quickly make its decision. Assertiveness is always defending the leadership's beliefs, but not ignoring the rights of others.

\section{(4) Justice}

According to Peterson and Seligman (2004), fairness is seeing and evaluating others, not allowing prejudices to influence decision-making, giving every fair opportunity to show and prove yourself. Also, according to these two authors, righteousness is also expressed in the spirit of collective, good cooperation with others, caring more about the collective than the individual, understanding and performing well their duties as a be a member of an organization; know-how to gather, and motivate team members to complete the work. Equity also manifests itself in the generosity, acceptance of employees' faults, and the willingness to give them other opportunities to improve.

\section{(5) Compliance}

Compliance with the law is reflected in the good leadership by the leader in observing the principles, regulations and regimes of the Party, the army and the unit; comply with, and abiding by duties assigned by superiors, always in the right time, in the military style. Compliant leaders are also the leaders who implement all duties and regulations, who let people follow. Compliance is to keep and comply with the rules set out to ensure fairness, professionalism, teamwork spirit and enhance the image of the company. Compliance can be roughly divided into three levels. Level 1 is to be performed because it's mandatory. Level 2 is done voluntarily and even at a higher voluntary level (level 3). In an enterprise, workers arrive on time at the office because they know if they are late, for any reason, they will affect my work and my colleagues.

Thus, it can be seen that the leader's characteristics/ qualities are the essential personal characteristics necessary to create conditions for an individual to be able to attract, influence, make others listen and follow. The leadership qualities and characteristics are considered as the 
characteristics that make up the leadership ability as well as the success of the leader.

\subsubsection{Group Factors That Belong to Leader Behaviors/ Styles}

\section{(1) The transforming leadership style}

The transforming leadership style has evolved over the years and is one of the most influential leadership style models (Burns, 1978). It is applied in virtually every field including in the military (Bradley \& Charbonneau, 2004).

Transformation leaders are willing to sacrifice their interests in return for the organization's common goals and values. The leadership of transformation is an exemplary model of working ethic towards the interests of groups, organizations and communities (Burns, 1978). The theory of empowering subordinates can develop and improve unexpected performance. This has also been argued by recent scholars (i.e. Nguyen, Mai, \& Huynh, 2019; Suong, Thanh, \& Dao, 2019; Doan, Nguyen, \& Nguyen, 2020; Do, Nguyen, Nguyen, Ha, \& Le, 2020; Tran, Lee, Nguyen, \& Srisittiratkul, 2020) that "transformation leaders have a charismatic leadership style, in which they try to inspire their subordinates to receive their trust and respect. They are also well aware of the mission they try to convey to their followers. It is further demonstrated that such leaders tend to have superior debate skills, technical expertise and persuasive competence. Bass and Avolio (1993) point out four key characteristics of transition leadership: personal attention, intellectual stimulation, inspiration, and ideal influence. Each concept focuses on the ways in which a leader can influence others to change him.

Personal attention is paying special attention to the needs of the group members (Bass \& Avolio, 1993). This helps leaders gain credibility from the pillars, providing encouragement and support to individuals in the organization in the form of training and mentoring (Gumusluoglu \& Ilsev, 2009). A leader who cares about an individual is someone who actively listens to others, accepts differences, and treats each member of the organization as a special individual rather than just an employee or colleague (Bass \& Avolio, 1993). This type of behavior is important when leading to changes in the working environment where a number of influential pillar groups exist.

Intellect stimulation is the ability to inspire, stimulate employees to analyze and handle problems in novel and different ways. In an intellectually-stimulating environment, people are not only allowed, but also encouraged to devise creative approaches to problem solving (Stewart, 2006). As businesses face increasingly complex challenges, this creativity becomes very important. Fullan (2005) argues that leadership is about mobilizing resources from everyone to solve complex backlog. This approach requires creativity and risk-taking, and must be supported and encouraged by the leader. The ultimate meaning of transformational leadership is to improve the members' ability to solve complex organizational problems (Leithwood et al., 1994), and the intellectual stimulation that allows the organization realize this goal by creating an environment where creative, innovative and even risky ideas are created.

Inspiration is the ability, with the help of members, to create vision and mission for the organization (Bass \& Avolio, 1993). Conversion leaders have a clear vision, they also want to pass this vision on to their subordinates to help achieve their goals. They motivate and inspire others by setting high standards, clear expectations and encouraging members to believe that they can achieve those goals and visions (Gumusluoglu \& Ilsev, 2009). In an increasingly complex competitive environment and with more and more competitors joining each year, it is important for leaders to understand the organization's goals and missions in that competitive market.

Ideal influence, also called charismatic leadership. It is the level where leaders behave in an admirable way, showing trust and taking a position that makes subordinates engage with leaders who have clear value trends and act as role models for subordinates. The ideal influence is the ability to model the kind of behavior that leaders expect to see in their subordinates, namely, the strong commitment to the organization's values, missions, and goals (Stewart, 2006). Team members want to emulate conversion leaders because they are people who always prioritize the needs of others, do not abuse their power for personal gain, share risks with their members in the organization, and have a humane and ethical behavior (Bass \& Avolio, 1993).

\section{(2) Trading leaders}

Burns' (1978) view of trading leadership states that rewards and punishments motivate people, and clear orders and subordinates must follow the direction of managers. Accordingly, the leader of a transaction is more inclined to work instead of building relationships with members. They will assign their subordinates with specific instructions, then, negotiate with them about the compensation and punishment during work. As a result, subordinates are motivated to increase productivity, while trying to gain more trust from the head.

According to Davies and Brighouse (2008), trading leaders are built from the need to get things done. Leaders present a style of trading leadership that takes over power and position, politics and rewards. With this style of leadership, superiors will put employees into a working machine instead of letting them be self-conscious. By clearly dividing tasks and assigning them with tight control, leaders will motivate 
employees to work hard to get the job done. In the military, transfer leadership is a style in which commanders use rewards and penalties to keep soldiers (military personnel) obeying orders (Odumeru \& Ogbonna, 2013).

The elements of trading leadership include (1) commendation and (2) management by exception (proactive) or problem discovery and handling for subordinates (Bass et al., 2003). Transaction leaders tend to exhibit behaviors related to corrective and building styles (Bass et al., 2003). Construction style involves rewarding elements. A random reward leader clarifies expectations for employees and gives recognition when they reach their goals (Bass et al., 2003). Leaders demonstrate rewarding behavior that clarifies goals and recognizes achievements to drive increased performance from individuals and teams. The remedy style is related to the leadership's "exceptional governance-initiative". Leaders who show this style always define standards, distinguish what constitutes inefficiency, and punish those who do not comply with these standards (Bass et al., 2003). This style is characterized by close supervision of deviations, mistakes, and prompt corrective actions.

\section{(3) Free leadership (Laissez-faire)}

With this leadership style, the leader will allow employees the right to make decisions, but the leader is still responsible for the decisions made. Free leadership is characterized by few guidelines from leadership, complete freedom for subordinates to make decisions, leaders providing the tools and resources needed, team members being expected to self-addressing issues, power given to followers, but leaders are still responsible for the group's decisions and actions. Freelance leadership can be effective in situations where team members are highly skilled, motivated and able to work on their own (Cherry, 2012). In other words, when team members have the skills to succeed, when team members are experts, when independence is valued. On the contrary, this style is not ideal in situations where team members lack the knowledge or experience they need to complete tasks and make decisions (Judge \& Piccolo, 2004). This leadership style is associated with negative outcomes, including poor job performance, low leadership performance, and low group satisfaction. Some people are not good at setting their own deadlines, managing their own projects, and solving problems on their own. In such situations, projects may go in the wrong direction and deadlines may be missed when team members do not receive sufficient guidance or feedback from the leaders.

\subsection{The Work Results of Subordinates}

Leadership is a social interaction process, where a leader is able to strongly influence the behavior of subordinates, employees and performance (Humphrey, 2002). Job satisfaction is an important factor contributing to improving the health and morale of workers, thus, significantly influencing workers' related behaviors at work such as productivity, absenteeism, turnover and colleague relationships (Becker \& Glascoff, 2014). Job satisfaction plays an important role in improving the financial status of organizations. Therefore, understanding employee satisfaction is an important goal of the organization (Aronson et al., 2006).

Olsen (1993) defines job satisfaction as the positive emotional response of employees to work when the value from work brings as expected. George and Jones (1996) suggest that satisfaction with an individual's job is a collection of his or her feelings and beliefs with his current job. Robbins (2002), the satisfaction of an individual's work is expressed through his attitude towards his job. When individuals who are satisfied with their work often have a positive attitude, and when they are dissatisfied with their job, they will have a negative attitude towards the job. Ivancevich et al. (2005) perceive that job satisfaction is expressed through an individual's attitude toward work and from that person's perception / perception of work that leads to his or her attitude towards work.

Consistent with previous studies, $\mathrm{Fu}$ and Deshpande (2014) found a positive correlation between managerial behavior and employee job satisfaction in mainland China. Managers with transformational leadership roles show greater interest in the feelings of others, leading to positive work-related outcomes. In a leadership study conducted in China, USA, Netherlands, Singapore, the UK and Japan. Bass (1993) shows that transformational leadership is positively related to leadership performance and employee satisfaction. Other scholars also suggest that transformation leadership is positively and significantly associated with employee job satisfaction (Ross \& Offermann, 1997). Studies have found that transformational leadership enhances employee commitment (Barling et al., 2000). Furthermore, transformation leadership can have a causal effect on employee performance, job satisfaction and organizational commitment (Bono \& Judge, 2003) (see Figure 1).

\section{Research Methodology}

We review the concepts and scales for variables in the research model, combined with selected qualitative research, offering a scale that best suits the research goals. Next, the author has consulted experts about the downstream translation of the scales to make corrections and give the first survey; Conducting a pilot survey of 20 subordinates (employees) at three corporations under the Ministry of Defense for the purpose of reassessing which questions are difficult to answer or which terms are difficult to understand, then the author corrected the second time survey; finally, the author consulted with three experts about the $2^{\text {nd }}$ revised survey 


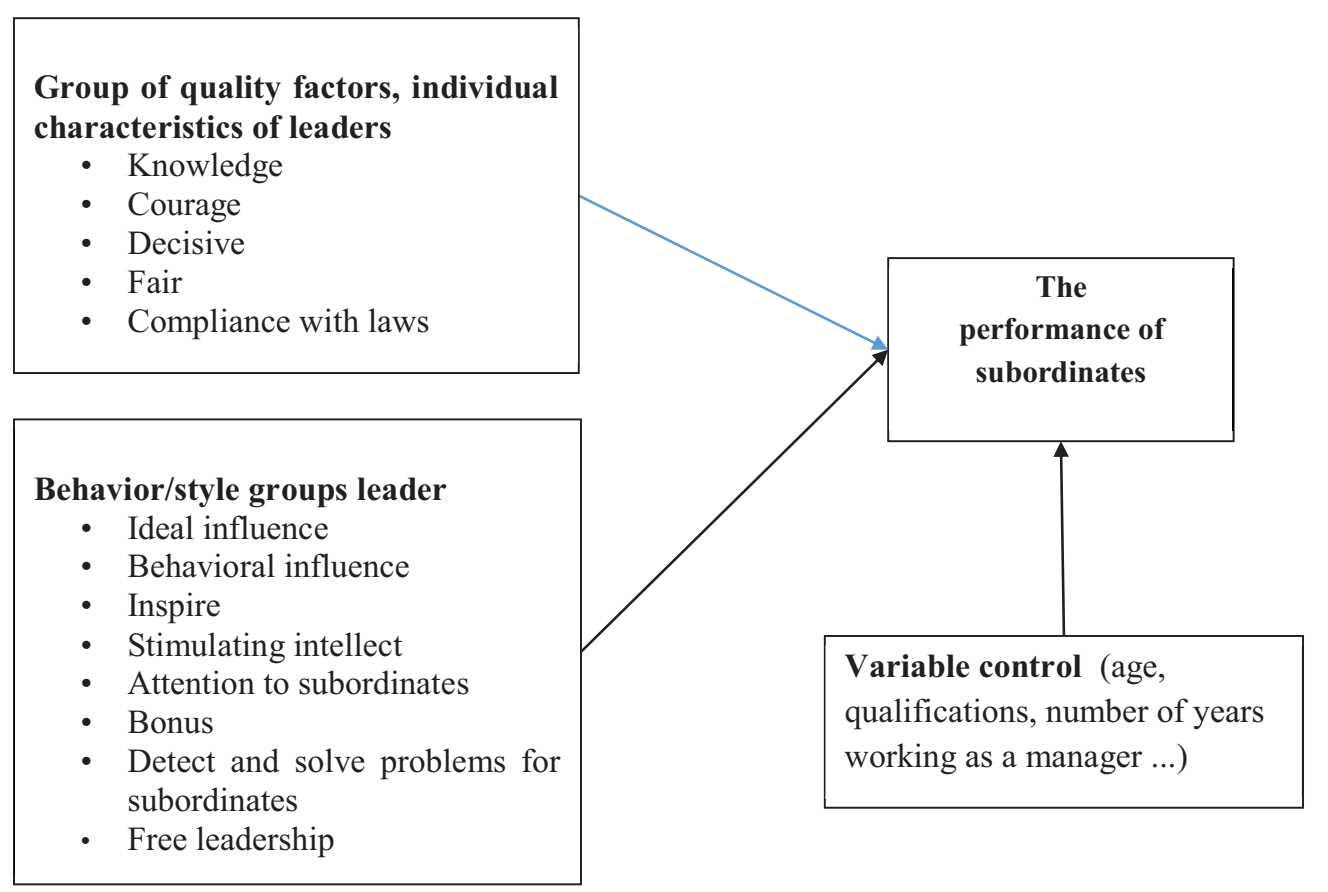

Figure 1: Research framework

questionnaire and brought it to the official questionnaire. The questionnaire content consists of four main parts:

Because of the difficulty in accessing and obtaining a full list of middle-class leaders in defense economic enterprises in Vietnam, the sample in this study was selected using a convenient sampling method. According to this method, the author conducted a survey at 15 defense economic enterprises. The questionnaire is sent directly to the respondents who are subordinates (subject to the survey) of the departments/divisions of defense economic enterprises. After collecting data and conducting review to remove the remaining substandard data, 1,181 completed questionnaires from 15 defense economic enterprises were retained. In terms of sample size, according to Hair et al. (1998), for EFA discovery factor analysis, the sample size must be at least five times the clauses in the scale. In the research model of the thesis, there are 71 observations used in factor analysis, so the minimum sample size to achieve is: $71 \times 5$ $=355$ observations. After receiving the questionnaires, the author has cleaned the information, filtered the questionnaire and coded the necessary information in the questionnaire, inputting and analyzing SPSS software table data. Next, the author conducts statistics to describe the collected data. Then, the following steps were taken: (1) assess the reliability of the scale by Cronbach's Alpha reliability coefficient, (2) EFA discovery factor analysis, and (3) testing multivariate regression models.

\section{Research Results}

In the study, 1,181 questionnaires were processed using SPSS software. The scales are preliminarily evaluated through Cronbach's Alpha reliability testing and calculation of the correlation coefficient of the total variable. In particular, the $\alpha$ coefficient of Cronbach's Alpha is a statistical test of the degree to which the items in the scale are correlated. The coefficient $\alpha$ in the range of $0.7-0.8$ is fine. A criterion for choosing a scale is when the coefficient $\alpha$ is 0.6 or higher. For the total correlation coefficient, variables with a total correlation coefficient lower than 0.4 will be excluded.

In this study, factor analysis will help us consider the possibility of reducing the number of 66 observed variables (58 independent variables, 8 dependent variables) to a small number of variables used to reflect specifically the impact of factors on the work results of subordinates. The factor analysis results are shown below (see Table 1 and 2). EFA discovery factor analysis for the independent variable is shown on Table 1, and EFA discovery factor analysis for the dependent variable is shown on Table 2.

Test results showed that the value of KMO reached $0.910>0.5$ and the Bartlett's Test Sig was 0.000 less than 0.05 , showing that eight observed variables KQ1, KQ2, KQ3, KQ4, KQ5, KQ6, KQ7, KQ8 are correlated with each other and perfectly suited to factor analysis (see Table 3). 
As can be seen from Table 3, for the results of factor analysis above, the total variance extracted is $50,445 \%$ greater than $50 \%$ and the eigenvalues value of the factor is greater than 1, so using factor analysis method is appropriate. Thus, we get the work results of subordinates with eight observed variables KQ1, KQ2, KQ3, KQ4, KQ5, KQ6, KQ7, KQ8.

Table 1: KMO test

\begin{tabular}{|l|c|c|}
\hline \multicolumn{3}{|c|}{ KMO and Bartlett's Test } \\
\hline $\begin{array}{l}\text { KMO (Kaiser-Meyer-Olkin of Sampling } \\
\text { Adequacy) }\end{array}$ & 0.838 \\
\hline \multirow{2}{*}{$\begin{array}{l}\text { Bartlett's } \\
\text { (Bartlett's Test } \\
\text { of Sphericity) }\end{array}$} & Approx. Chi-Square & 27920.013 \\
\cline { 2 - 3 } & Df & 1596 \\
\hline
\end{tabular}

Table 2: KMO test

\begin{tabular}{|l|c|c|}
\hline \multicolumn{3}{|c|}{ KMO and Bartlett's Test } \\
\hline $\begin{array}{l}\text { KMO (Kaiser-Meyer-Olkin of Sampling } \\
\text { Adequacy) }\end{array}$ & 0.910 \\
\hline \multirow{3}{*}{$\begin{array}{l}\text { Bartlett's (Bartlett's } \\
\text { Test of Sphericity) }\end{array}$} & Approx. Chi-Square & 3214.495 \\
\cline { 2 - 3 } & Df & 28 \\
\cline { 2 - 3 } & Sig. & 0.000 \\
\hline
\end{tabular}

We analyze the relationship between the components of middle leadership and the performance of subordinates. After performing correlation analysis, the subsequent regression analysis aims to determine the linear relationship between the independent variables and the dependent variable $\mathrm{KQ}$ (see Table 4).

As can be seen from Table 4, the results of the first regression analysis show that there is no clear link between the compliance of middle managers and free leaders with the results of subordinates' work $(\mathrm{p}>0.05)$. We proceed to

Table 3: EFA results for the dependent variables

\begin{tabular}{|l|c|}
\hline \multicolumn{1}{|c|}{ Observed variables } & Load factor \\
\hline KQ1 & 0.777 \\
\hline KQ7 & 0.762 \\
\hline KQ6 & 0.744 \\
\hline KQ8 & 0.730 \\
\hline KQ3 & 0.705 \\
\hline KQ4 & 0.663 \\
\hline KQ5 & 0.657 \\
\hline KQ2 & 0.631 \\
\hline Eigenvalues & $\mathbf{4 . 0 3 6}$ \\
\hline Extraction variance & $\mathbf{5 0 . 4 4 5 \%}$ \\
\hline
\end{tabular}

Table 4: First regression analysis

\begin{tabular}{|c|c|c|c|c|c|}
\hline \multirow{2}{*}{ Model } & \multicolumn{2}{|c|}{ Unstandardized Coefficients } & \multirow{2}{*}{$\begin{array}{c}\text { Standardized Coefficients } \\
\text { Beta }\end{array}$} & \multirow{2}{*}{$\mathbf{P}$} & \multirow{2}{*}{ VIF } \\
\hline & B & Std. Error & & & \\
\hline (Constant) & -1.087 & 0.166 & & 0.000 & \\
\hline $\mathrm{HB}$ & 0.243 & 0.021 & 0.263 & 0.000 & 1.206 \\
\hline CD & 0.061 & 0.022 & 0.059 & 0.006 & 1.109 \\
\hline QD & 0.068 & 0.018 & 0.079 & 0.000 & 1.026 \\
\hline $\mathrm{CB}$ & 0.185 & 0.020 & 0.215 & 0.000 & 1.268 \\
\hline $\mathrm{CH}$ & 0.038 & 0.024 & 0.033 & 0.126 & 1.125 \\
\hline PCHV & 0.042 & 0.018 & 0.051 & 0.020 & 1.161 \\
\hline $\mathrm{TCH}$ & 0.160 & 0.021 & 0.173 & 0.000 & 1.216 \\
\hline TT & 0.059 & 0.017 & 0.074 & 0.000 & 1.039 \\
\hline QT & 0.240 & 0.020 & 0.262 & 0.000 & 1.160 \\
\hline KT & 0.113 & 0.020 & 0.117 & 0.000 & 1.077 \\
\hline $\mathrm{PH}$ & 0.071 & 0.017 & 0.084 & 0.000 & 1.053 \\
\hline TD & 0.024 & 0.014 & 0.035 & 0.086 & 1.033 \\
\hline \multicolumn{6}{|l|}{ R square: 0.516} \\
\hline \multicolumn{6}{|c|}{$\mathrm{P}($ Anova $): 0.000$} \\
\hline \multicolumn{6}{|c|}{ Durbin - Watson: 1.980} \\
\hline
\end{tabular}


remove these two factors from the model and run the second regression analysis (see Table 5).

As can be seen from Table 5, testing assumptions about autocorrelation, variance of constant error, standard distribution of residuals, and multi-plus checks are all required. The coefficient $\mathrm{R}$ is squared: the square root coefficient $\mathrm{R}$ helps to measure the relevance of the model with the meaning that the independent variables explain how much of the variation of the dependent variable can be explained. Here, the coefficient of R squared corrected in the results of the second regression analysis is 0.514 , thus, satisfactory. The independent variables explain $51.4 \%$ $(>50 \%)$ of the variation of the dependent variable. The regression equation has the form:

$$
\begin{aligned}
Y= & b+a 1 X 1+a 2 X 2+a 3 X 3+a 4 X 4+a 5 X 5+a 6 X 6+ \\
& a 7 X 7+a 8 X 8+a 9 X 9+a 10 X 10
\end{aligned}
$$

Of which:

$\mathrm{Y}=\mathrm{KQ} ; \mathrm{X} 1=\mathrm{HB}, \mathrm{X} 2=\mathrm{CD} ; \mathrm{X} 3=\mathrm{QD} ; \mathrm{X} 4=\mathrm{CB} ; \mathrm{X} 5=$ PCHV; X6 = TCH, X7 = TT; X8 = QT; X9 = KT; $\mathrm{X} 10=\mathrm{PH}$

Standardized regression model:

$$
\begin{aligned}
\mathrm{Y}= & 0.269 \mathrm{X} 1+0.065 \mathrm{X} 2+0.077 \mathrm{X} 3+0.218 \mathrm{X} 4+0.053 \\
& \mathrm{X} 5+0.174 \mathrm{X} 6+0.075 \mathrm{X} 7+0.265 \mathrm{X} 8+0.120 \mathrm{X} 9 \\
& +0.085 \mathrm{X} 10
\end{aligned}
$$

ANOVA analysis result for sig $=0.000<0.05$. Thus, the multivariate regression model is consistent with the surveyed data. Through the regression model, we see:

The knowledge of middle managers has the strongest influence on the performance of subordinates with the standardized Beta of 0.269 . What this means is that, in the case of other factors that are constant (Attention, Justice, Inspiration, Commendation, Detect and solve problems for granted, Intellectually stimulating, Reasonable influence), the management knowledge of the middle managers has increased by 1 unit, if the knowledge of the middle managers increases by 1 unit, the results of the subordinates' work will increase to 0.262 .

The second strongest influence on the performance of subordinates is the interest of middle managers $(\beta=0.265)$. This means that, in the case of other factors that are constant (Knowledge, Justice, Inspiration, Commendation, Detection and problem solving for granted, Intellectually stimulating, Reasonable influence Initiative and Business Leaders' Persistence), if the interest of mid-level managers increases by 1 unit, the work results of subordinates will increase to 0.265 .

The equity of middle managers is the third most important factor affecting the performance of subordinates $(\beta=0.218)$. This means that, in the case of other factors that are constant (Knowledge, Attention, Inspiration, Commendation, Detection and problem solving for granted, Intellectually Stimulating, Reasonable Influence In the middle of the Presidency, the determination and courage of

Table 5: Second regression analysis

\begin{tabular}{|l|c|c|c|c|c|}
\hline \multirow{2}{*}{ Model } & \multicolumn{2}{|c|}{ Unstandardized Coefficients } & Standardized Coefficients & \multirow{2}{*}{ P } & \multirow{2}{*}{ VIF } \\
\cline { 2 - 5 } & B & Std. Error & Beta & 0.000 & \\
\hline (Constant) & -0.940 & 0.153 & & 0.000 & 1.187 \\
\hline HB & 0.249 & 0.020 & 0.269 & 0.002 & 1.087 \\
\hline CD & 0.066 & 0.022 & 0.065 & 0.000 & 1.025 \\
\hline CB & 0.067 & 0.018 & 0.077 & 0.000 & 1.262 \\
\hline PCHV & 0.188 & 0.020 & 0.218 & 0.015 & 1.159 \\
\hline TCH & 0.043 & 0.018 & 0.053 & 0.000 & 1.216 \\
\hline TT & 0.161 & 0.021 & 0.174 & 0.000 & 1.036 \\
\hline QT & 0.061 & 0.017 & 0.075 & 0.000 & 1.156 \\
\hline KT & 0.242 & 0.020 & 0.265 & 0.000 & 1.069 \\
\hline PH & 0.115 & 0.020 & 0.120 & 0.000 & 1.045 \\
\hline R square: 0.514 & 0.072 & 0.017 & 0.085 & & \\
\hline P(Anova): 0.000 & \multicolumn{7}{|l}{} & & & \\
\hline Durbin - Watson: 1.972 &
\end{tabular}


the middle level manager is unchanged), if the equity of the middle level manager increases by 1 unit, the work result of the subordinate will increase to 0.218 .

The fourth strongest influence on the work results of subordinates is Inspiration of middle managers $(\beta=0.174)$. What this means is: in the case of other factors that are constant (Knowledge, Attention, Justice, Commendation, Detect and solve problems for granted, Intellectually stimulating, Reasonable influence The firm's inspirations and persistence remain the same) if the inspiration of the middle manager increases by 1 unit, the work result of the subordinates will increase to 0.174 .

The reward of middle managers is the fifth most influential factor on the performance of subordinates $(\beta=$ 0.12 ). What this means is: in the case of other factors that are constant (Knowledge, Attention, Equity, Inspiration, Issuing and problem solving for granted, Intelligence stimulation, Influence ideals, assertiveness and courage of mid-level managers), if the reward of middle-class managers increases by 1 unit, the work results of subordinates will increase by 0.12 .

Factors: Detecting and solving problems for subordinates, Intellectual stimulation, Ideal influence, Assertiveness and Courage of mid-level cadres all positively influence the work results of subordinates right with a standardized Beta coefficient in turn, $\mathrm{PH}(\beta=0.085) ; \mathrm{PCHV}(\beta=0.053)$; $\mathrm{QD}(\beta$ $=0.077) ; \mathrm{CD}(\beta=0.065)$ and interpreted similarly as above.

\section{Discussion and Conclusion}

First, the knowledge of middle managers has the strongest influence on the performance of subordinates (standardized Beta is 0.269). This shows that the senior staff group attaches great importance to the understanding of middle management in executive management. The knowledge of mid-level managers is shown in understanding the tasks assigned by strategic staff and implementing these tasks scientifically as well as forecasting and handling flexible situations when new or unusual elements occur to give quick, efficient and comprehensive work-solving ideas. Middle managers with their own knowledge will always have full and clear answers to technical problems, help subordinates be more confident in doing their jobs, and be an example of inquisitive learning, self-training for subordinates.

Second, the interest of middle managers is the second most powerful influence on the performance of subordinates (standardized Beta is 0.265). This shows that the senior staff group attaches great importance to the middle management's attention in executive management, the more years of dedication, the more attention the managers need. The concern of the superiors is to show the understanding of subordinates, understand the differences in the members' abilities, needs and aspirations, understand that each person has different advantages, different strengths, how to arrange and assign work clearly and in accordance with the conditions and capabilities of each person, thereby promoting their strengths and helping them develop themselves at work. Therefore, a central manager who cares about subordinates also takes time to guide and train subordinates, taking care of issues in the lives of subordinates, not just in the job aspect.

Third, along with understanding the strengths and weaknesses of subordinates, believing in assigning subordinates, the justice in the assessment of middle managers plays an important role in improving efficiency, work results and satisfaction of subordinates. This is the third most powerful factor affecting the performance of subordinates (standardized Beta coefficient is 0.218 ). The fairness of middle managers here is not just fair treatment, no prejudice, no bias towards subordinates; it is fair assessment of contributions and shortcomings that limit the shortcomings of subordinates, but also show the humanity, kindness of the manager, altruistic, accepting shortcomings, mistakes of subordinates and willingness to give subordinates another opportunity to make amend and complete, without showing trashing and bad impressions of the negligence of others.

Fourth, accompanying the fairness in the evaluation is the reward of the middle managers to improve the work results and the satisfaction of the subordinates (standardized Beta coefficient is 0.12). In order for the reward to be clear and right to the right people, middle managers must first provide under the necessary support tools so that subordinates can complete the assigned work, and clearly define responsibilities of each person when performing the job. If the subordinates fulfill the work objectives as set out, the superior must show their recognition and have incentive and timely rewards to encourage and reward.

Fifth, in addition to understanding and caring for subordinates, trusting subordinates to work, showing fairness and reward, for subordinates to perform well their assigned tasks, middle managers still need to inspire subordinates to work. The inspiration of middle managers has a positive influence on the performance of the work as well as the satisfaction of subordinates (standardized Beta coefficient is 0.174 ). In order to inspire subordinates to work, middle managers must show themselves to be optimistic, communicate so that subordinates feel a bright, convincing future, and show solid confidence to make sure that the goals will be achieved, thereby describing the work for subordinates in an attractive way, and building a united team to create a comfortable working spirit for everyone.

Sixth, the research results show a positive relationship between the intellectual stimulation of middle managers and the work results of subordinates (standardized Beta coefficient is 0.061). Middle managers who stimulate their minds must first be creative people, always looking for different perspectives when solving problems as well as 
offering new approaches to get things done. They always encourage subordinates to be creative in order to be effective at work, encourage people to think about solving old problems in a new way, and with their knowledge base, they know the problems and create opportunities for people to express their opinions.

Seventh, detecting and solving problems for subordinates of mid-level managers is also a positive factor affecting the work results of subordinates (standardized Beta coefficient is 0.085). In order to proactively manage errors in the working process of the subordinates, the middle manager clearly tells the subordinates what the subordinates know to perform well. Next, the manager will follow closely, warn subordinates to know errors, shortcomings, deviations that may occur in the process of working, and if any defects, errors, deviations occur. After that, instructing the subordinates how to correct and before taking the form of discipline, the middle managers clearly explained to the subordinates.

Eighth, the research results also show that the assertiveness of middle managers affects the performance of subordinates (standardized Beta is 0.077). Assertiveness shows the manager does not hesitate in situations, opportunities and quickly makes his decision; always take the initiative in deciding every task and if there are situations where there are many different opinions, the manager always decides an action plan, responsible for his actions.

Ninth, courage is also the outstanding quality of the commander in the army and is also a factor that has a positive effect on the work of his subordinates (standardized Beta is 0.065). Courage manifests itself in the fact that commanders show willingness to accept, withstand pressure and be able to overcome the pressure of work; no hesitation, faltering in front of difficulties, hardships and deprivation; ready to face difficulties, challenges, dangers. The courage of the manager is also integrity, never eluding, rejecting his own actions and words and being willing to take responsibility before his decisions or matters within his scope.

Finally, the attraction of the leader (idealized influence) is described as the ideal model, which the leader or manager with the leadership role should build with the subordinates. As a level of officials who have the function to implement tasks, communicate the ideals, goals of senior leaders in the enterprise to the executing staff, these middle managers must have high standards of competency and morality, respected and trusted by workers. Ideal influence indicates the trust of subordinates for the direct leader of the school, upholding faith and respect, showing their dedication to leadership, attract them and hope, and set an example for them. The research results show that this ideal influence has a positive relationship to the work results of subordinates (standardized Beta is 0.053).

\section{References}

Aronson, Z. H., Reilly, R. R., \& Lynn, G. S. (2006). The impact of leader personality on new product development teamwork and performance: The moderating role of uncertainty. Journal of Engineering and Technology Management, 23(3), 221-247.

Barling, J., Slater, F., \& Kelloway, E. K. (2000). Transformational leadership and emotional intelligence: An exploratory study. Leadership \& Organization Development Journal, 21(3), 157-161. https://doi.org/10.1108/01437730010325040

Bass, B. M., \& Avolio, B. J. (1993). Transformational leadership and organizational culture. Public Administration Quarterly, 112-121.

Bass, B. M., Avolio, B. J., Jung, D. I., \& Berson, Y. (2003). Predicting unit performance by assessing transformational and transactional leadership. Journal of Applied Psychology, 88(2), 207-218. https://doi.org/10.1037/0021-9010.88.2.207

Becker, C. M., \& Glascoff, M. A. (2014). Process measures: A leadership tool for management. The TQM Journal, 26(1), 5062. https://doi.org/10.1108/TQM-02-2013-0018

Bono, J. E., \& Judge, T. A. (2003). Core self-evaluations: A review of the trait and its role in job satisfaction and job performance. European Journal of Personality, 17(S1), S5S18.

Boyatzis, R. E. (1982). The competent manager: A model for effective performance. John Wiley \& Sons.

Bradley, P., \& Charbonneau, D. (2004). Transformational leadership: Something new, something old. Canadian Military Journal, 5(1), 7-14.

Burns, J. M. (1978). Leadership. New York, NY: Harper and Row.

Cherry, K. (2012). Leadership theories. New York, NY: Harper and Row.

Davies, B., \& Brighouse, T. (Eds.). (2008). Passionate leadership in education. Thousand Oaks, CA: Sage Publications.

Do, D. T., Nguyen, T. H., Nguyen, T. H. N., Ha, H. H., \& Le, T. T. (2020). The Influence of Leadership Style on Accountants' Commitment with Enterprise: An Empirical Study on Vietnamese FDI Firms. Journal of Asian Finance, Economics, and Business, 7(3), 235-243. https://doi.org/10.13106/ jafeb.2020.vol7.no3.235

Doan, T. T. T., Nguyen, L. C. T., \& Nguyen, T. D. N. (2020). Emotional Intelligence and Project Success: The Roles of Transformational Leadership and Organizational Commitment. Journal of Asian Finance, Economics, and Business, 7(3), 223233. https://doi.org/10.13106/jafeb.2020.vo17.no3.223

Fu, W., \& Deshpande, S. P. (2014). The impact of caring climate, job satisfaction, and organizational commitment on job performance of employees in a China's insurance company. Journal of Business Ethics, 124(2), 339-349.

Fullan, M. (2005, June). Turnaround leadership. In The Educational Forum (Vol. 69, No. 2, pp. 174-181). Taylor \& Francis Group. 
George, J. M., \& Jones, G. R. (1996). The experience of work and turnover intentions: Interactive effects of value attainment, job satisfaction, and positive mood. Journal of Applied Psychology, 81(3), 318.

Gumusluoglu, L., \& Ilsev, A. (2009). Transformational leadership, creativity, and organizational innovation. Journal of Business Research, 62(4), 461-473.

Hair, J. F., Anderson, R. E., Tatham, R. L., \& Black, W. C. (1998). Multivariate Data Analysis (5th ed.). Englewood Cliffs, NJ: Prentice-Hall.

Humphrey, R. H. (2002). The many faces of emotional leadership. The Leadership Quarterly, 13(5), 493-504.

Ivancevich, J. M., Matteson, M. T., \& Richards, E. P. (1985). Whos liable for stress on the job. Harvard Business Review, 63(2), 60. https://hbr.org/1985/03/whos-liable-for-stress-on-the-job

Judge, T. A., Bono, J. E., Ilies, R., \& Gerhardt, M. W. (2002). Personality and leadership: a qualitative and quantitative review. Journal of Applied Psychology, 87(4), 765-780. https:// https://doi.org/10.1037/0021-9010.87.

Judge, T. A., \& Piccolo, R. F. (2004). Transformational and transactional leadership: a meta-analytic test of their relative validity. Journal of Applied Psychology, 89(5), 755-768. https://doi.org/10.1037/0021-9010.89.5.755

Leithwood, K., Begley, P. T., \& Cousins, J. B. (1994). Performance appraisal and selection of school leaders: Selection processes and measurement issues. In: Developing Expert Leadership for Future Schools (pp. 228-252). London, UK: Routledge.

McClelland, D. C. (1973). Testing for competence rather than for intelligence. American Psychologist, 28(1), 1-14. https://doi. org $/ 10.1037 / \mathrm{h} 0034092$

McClelland, D. C. (1976). A guide to job competency assessment. Boston, MA: McBer.

McLagan, P. (1980). Competency models. Training and Development Journal, 34(12), 22-26.

McLagan, P. A. (1989). Models for HRD practice. Training \& Development Journal, 43(9), 49-60.

Nguyen, H. M., Mai, L. T., \& Huynh, T. L. (2019). The Role of Transformational Leadership toward Work Performance through Intrinsic Motivation: A Study in the Pharmaceutical Field in Vietnam. Journal of Asian Finance, Economics and Business, 6(4), 201-212. https://doi.org/10.13106/jafeb.2019. vol6.no4.201
Odumeru, J. A., \& Ogbonna, I. G. (2013). Transformational vs. transactional leadership theories: Evidence in literature. International Review of Management and Business Research, 2(2), 355-361. Available at: https://www. irmbrjournal.com/papers/1371451049.pdf

Olsen, D. (1993). Work satisfaction and stress in the first and third year of academic appointment. The Journal of Higher Education, 64(4), 453-471.

Peterson, C., \& Seligman, M. E. (2004). Character strengths and virtues: A handbook and classification (Vol. 1). Oxford, UK: Oxford University Press.

Prahalad, C. K., \& Hamel, G. (2006). The core competence of the corporation. In: Strategische unternehmungsplanungstrategische unternehmungsführung (pp. 275-292). Berlin, Heidelberg: Springer.

Robbins, R., Stoltenberg, C., Robbins, S., \& Ross, J. M. (2002). Marital satisfaction and Cherokee language fluency. Measurement and Evaluation in Counseling and Development, 35(1), 27-34.

Ross, S. M., \& Offermann, L. R. (1997). Transformational leaders: Measurement of personality attributes and work group performance. Personality and Social Psychology Bulletin, 23(10), 1078-1086.

Rothwell, W. J., \& Lindholm, J.E.(1999). Competency identification, modelling and assessment in the USA. International Journal of Training and Development, 3(2), 90-105.

Stewart, J. (2006). Transformational leadership: An evolving concept examined through the works of Burns, Bass, Avolio, and Leithwood. Canadian Journal of Educational Administration and Policy, 54(2006). Available at: https://journalhosting. ucalgary.ca/index.php/cjeap/article/view/42735

Suong, H. T. T., Thanh, D.D., \& Dao, T. T. X. (2019). The Impact of Leadership Styles on the Engagement of Cadres, Lecturers and Staff at Public Universities-Evidence from Vietnam. Journal of Asian Finance, Economics and Business, 6(1), 273-280. http:// doi.org/10.13106/jafeb.2019.vol6.no1.273

Tran, D. T., Lee, L. Y., Nguyen, P. T., \& Srisittiratkul, W. (2020). How Leader Characteristics and Leader Member Exchange Lead to Social Capital and Job Performance. Journal of Asian Finance, Economics, and Business, 7(1), 269-278. https://doi. org/10.13106/jafeb.2020.vol7.no1.269 